University of Nebraska - Lincoln

DigitalCommons@University of Nebraska - Lincoln

College of Law, Faculty Publications

Law, College of

2009

\title{
A Decade of Change in Sixth Amendment Confrontation Doctrine
}

Roger Kirst

University of Nebraska - Lincoln, rkirst1@unl.edu

Follow this and additional works at: https://digitalcommons.unl.edu/lawfacpub

Part of the Legal Studies Commons

Kirst, Roger, "A Decade of Change in Sixth Amendment Confrontation Doctrine" (2009). College of Law, Faculty Publications. 3.

https://digitalcommons.unl.edu/lawfacpub/3

This Article is brought to you for free and open access by the Law, College of at DigitalCommons@University of Nebraska - Lincoln. It has been accepted for inclusion in College of Law, Faculty Publications by an authorized administrator of DigitalCommons@University of Nebraska - Lincoln. 


\title{
International Commentary on Evidence
}

Volume 6, Issue 2 2009 Article 5

EVIDENCE DURING THE TEN YEARS OF ICE

\section{A Decade of Change in Sixth Amendment Confrontation Doctrine}

\author{
Roger W. Kirst*
}




\title{
A Decade of Change in Sixth Amendment Confrontation Doctrine*
}

\author{
Roger W. Kirst
}

\begin{abstract}
The United States Supreme Court brought new prominence to Sixth Amendment confrontation doctrine in 2004 when it announced its testimonial interpretation in Crawford v. Washington. This essay describes how confrontation doctrine was changed in the last decade by Crawford and the Court's subsequent decisions in Davis v. Washington and Giles v. California. It examines what the disagreements among the five opinions in Giles suggest about whether the Court will continue to rely so strongly on historical hearsay doctrine to interpret the Confrontation Clause. It discusses other confrontation issues the Supreme Court will face in future cases.
\end{abstract}

KEYWORDS: Sixth Amendment, confrontation, testimonial, hearsay, Crawford

${ }^{*}$ Henry M. Grether Professor of Law, University of Nebraska College of Law. Research for this article was supported by a grant from the Law College McCollum Research Fund. I appreciate the assistance of Richard Moberly and John Lenich. 
The most notable event for Sixth Amendment confrontation doctrine in the last decade was the 2004 decision of the United States Supreme Court in Crawford $v$. Washington. ${ }^{1}$ Justice Scalia's majority opinion declared that the Court had strayed from the original meaning of the Confrontation Clause because the rationale in Ohio v. Roberts ${ }^{2}$ allowed the prosecution to use all kinds of hearsay evidence upon a judicial finding that it was reliable. Justice Scalia announced that the historical evidence showed that the Clause was directed at excluding "testimonial" statements of declarants who did not testify at trial. ${ }^{3}$ Under the Crawford interpretation, testimonial statements could not be used by the prosecution unless the absent declarant was unavailable and the defendant had a prior opportunity to cross-examine the declarant. Justice Scalia conceded that his Crawford opinion did not provide a comprehensive definition of "testimonial" but he declared that interim uncertainty until the Court could decide additional cases was better than the inherent unpredictability produced by Roberts. ${ }^{4}$

The 7-2 vote in Crawford created the impression that Justice Scalia's testimonial theory of confrontation had firmly set the Supreme Court on a new course. Chief Justice Rehnquist argued that it was not necessary to reject Roberts to decide Crawford and that the new testimonial theory was not a clearly better reading of the historical evidence than in prior opinions, but only Justice O'Connor joined his concurring opinion. ${ }^{5}$

When the Court returned to confrontation doctrine two years later in Davis $v$. Washington, ${ }^{6}$ neither Chief Justice Rehnquist nor Justice O'Connor was serving on the Court. Once again Justice Scalia wrote the opinion for the Court; it provided more detailed guidance on whether a victim's statement to law enforcement was testimonial or nontestimonial. Justice Scalia had even stronger support in Davis from an 8-1 vote; no other Justice joined Justice Thomas's opinion in which he argued that the "testimonial" label should apply only to formalized statements to the police and not to statements during informal police questioning. ${ }^{7}$

This year, Justice Scalia again announced the judgment of the Court when it addressed forfeiture of confrontation rights by wrongdoing in Giles v. California. ${ }^{8}$ Justice Scalia concluded in his opinion that there was a founding-era forfeiture exception to the right of confrontation, but that it applied "only when the defendant

1541 U.S. 36 (2004).

2448 U.S. 56 (1980).

3541 U.S. at $50-53$.

${ }^{4} I d$. at 68 n. 10.

${ }^{5}$ Id. at 69 (Rehnquist, C.J. \& O'Connor, J., concurring).

${ }^{6} 547$ U.S. 813 (2006).

7547 U.S. at 834 (Thomas, J., concurring in the judgment in part and dissenting in part).

8128 S. Ct. 2678 (2008). 
engaged in conduct designed to prevent the witness from testifying." 9 While the vote to vacate the California judgment was 6-3, Justice Scalia did not have as much support for his reasoning as he had in Crawford or Davis. Instead, the Justices explained their views in five different opinions. Justice Scalia was fully supported by only Chief Justice Roberts. Justice Thomas and Justice Alito joined Justice Scalia's opinion, but each also wrote separately to argue for a narrower definition of a testimonial statement that Justice Scalia did not accept. ${ }^{10}$ Justice Souter was joined by Justice Ginsburg in an opinion that concurred with Justice Scalia in part; Justice Souter declared that the historical evidence alone did not provide adequate detail to answer the question raised by Giles and provided his own view on how the forfeiture rule should work in practice. ${ }^{11}$ Justice Breyer's dissenting opinion was joined by Justice Stevens and Justice Kennedy; it rejected Justice Scalia's standard and sought common ground with Justice Souter and Justice Ginsburg on the operation of the forfeiture rule. $^{12}$

The last time the Justices wrote as many opinions in a confrontation case as they did in Giles was in 1999 in Lilly v. Virginia. ${ }^{13}$ In retrospect, Lilly provided more notice than was appreciated at the time that the Court was ready to reformulate confrontation doctrine. While it was not possible to predict in 1999 whose view would prevail, the opinions in Lilly sent a clear signal that some Justices had doubts about the direction in which confrontation doctrine was then developing. Justice Scalia's latest opinion in Giles continues to show his confident rejection of any similar doubt about Crawford's testimonial interpretation, but the votes of the other eight Justices may tell a different story. As a result, assessing the future direction of confrontation doctrine requires attention to the views of individual Justices.

It may not take long to learn what the multiple opinions in Giles could mean for the future direction of confrontation doctrine. The Supreme Court will hear argument in November in Melendez-Diaz, a case from Massachusetts in which a defendant objected on confrontation grounds to the State's use of a forensic laboratory report in a drug prosecution without calling the analyst as a witness. ${ }^{14}$ The defendant's objection was overruled in the trial court on the basis of Massachusetts precedent that permitted the prosecution to use a drug analysis certificate as a

9 Id. at 2683.

${ }^{10}$ Id. at 2693 (Thomas, J., concurring); id. at 2694 (Alito, J., concurring).

11 Id. at 2694 (Souter \& Ginsburg, JJ., concurring in part).

12 Id. at 2695 (Breyer, Stevens \& Kennedy, JJ., dissenting).

13527 U.S. 116 (1999); id. at 140 (Breyer, J., concurring); id. at 143 (Scalia, J., concurring); id. (Thomas, J., concurring); id. at 144 (Rehnquist, C.J. \& O'Connor \& Kennedy, JJ., concurring in the judgment).

14 Commonwealth v. Melendez-Diaz, 870 N.E.2d 676 (Mass. App. Ct.) (unpublished opinion available at 2007 WL 2189152); rev. denied, 874 N.E.2d 407 (Mass. 2007); cert. granted, 128 S. Ct. 1647 (Mar. 17, 2008) (No. 07-591). 
business record of the laboratory. ${ }^{15}$ That precedent had been grounded in part on a brief description in Crawford of business records as an example of a nontestimonial statement. $^{16}$

The opinions in Giles suggest that it is unlikely the Justices will consider the brief mention of business records in Crawford as sufficient to resolve the issue in Melendez-Diaz. There had been a similar brief endorsement of the forfeiture rule in both Crawford $^{17}$ and Davis, ${ }^{18}$ but none of the Justices in Giles thought they were limited by what Crawford said about forfeiture. The opinions in Melendez-Diaz may again present different readings of the historical record as well as a continuation of the debate about whether the historical record alone can provide a sufficient foundation for answering every confrontation question that may arise in modern criminal prosecutions.

This Article will review the last ten years of confrontation doctrine and consider what might lie ahead for some topics the Court has not yet addressed. Part I will outline confrontation doctrine before it was revised by Crawford. Part II will discuss the effect of Crawford and subsequent cases. Part III will examine the questions that were raised by Giles in 2008. Part IV will describe the issues the Court will face later this year in Melendez-Diaz. Part V will describe other important topics the appellate courts have been addressing as they wait for further guidance from the Supreme Court.

\section{Confrontation Doctrine Before Crawford}

The modern era of confrontation doctrine began in 1965 when the Supreme Court held that the Confrontation Clause applied to state criminal trials. ${ }^{19}$ At the beginning the Court found it sufficient to decide most confrontation cases on their facts without adopting an overall theory of confrontation. Some early cases held that there was a confrontation violation if the prosecution used a confession from an accomplice who did not testify at trial, ${ }^{20}$ but no violation if the accomplice did testify. ${ }^{21}$ Other early cases held that there was a confrontation violation if the prosecution used prior testimony of a witness who did not appear at trial, ${ }^{22}$ but no violation if the witness

\footnotetext{
15 Melendez-Diaz, 2007 WL 2189152 at *4, citing Commonwealth v. Verde, 827 N.E.2d 701 (Mass. 2005).

16 Crawford, 541 U.S. at 56.

17 Id. at 62.

18547 U.S. at 833.

19 Pointer v. Texas, 380 U.S. 400 (1965).

20 Douglas v. Alabama, 380 U.S. 415 (1965).

21 Nelson v. O'Neill, 402 U.S. 622.

22 Barber v. Page, 390 U.S. 719 (1968).
} 
could be cross-examined at trial. ${ }^{23}$ There was also no violation if the witness was unavailable and the defendant had examined or cross-examined the witness when the prior testimony was given. ${ }^{24}$ Later the Court began to address other kinds of hearsay statements, holding that there was no confrontation violation if the out-of-court statement used by the prosecution was a co-conspirator statement ${ }^{25}$ and no violation if the out-of-court statement was an excited utterance. ${ }^{26}$

Even the 1980 opinion of Justice Blackmun in Roberts was consistent in its result with what he described as the Court's practice up to that time of developing confrontation doctrine in "the common-law tradition, ... building on past decisions, drawing on new experience, and responding to changing conditions." 27 Justice Blackmun devoted much of his Roberts opinion to describing the specific facts of the case and explaining why the Court's precedent in California v. Green allowed the prosecution to use the preliminary hearing testimony of the missing witness. ${ }^{28}$ His explanation relied on the examination of the witness by defense counsel at the preliminary hearing as sufficient to provide confrontation. Justice Blackmun explicitly said that confrontation analysis did not depend on the inherent reliability or unreliability of the prior testimony that was offered by the prosecution against the defendant. $^{29}$

Why then did Justice Scalia dramatically reject the reliability test of Roberts in his Crawford opinion? The foundation for the reliability test did not come from the holding of Roberts, but rather from Justice Blackmun's brief discussion of a "general approach" to confrontation doctrine that he derived from the Court's decisions.

In sum, when a hearsay declarant is not present for cross-examination at trial, the Confrontation Clause normally requires a showing that he is unavailable. Even then, his statement is admissible only if it bears adequate "indicia of reliability." Reliability can be inferred without more in a case where the evidence falls within a firmly rooted hearsay exception. In other cases, the evidence must be excluded, at least absent a showing of particularized guarantees of trustworthiness. ${ }^{30}$

Justice Blackmun did not rely on his own general theory to explain the outcome in

${ }^{23}$ California v. Green, 399 U.S. 149 (1970).

${ }^{24}$ Id.; Ohio v. Roberts, 448 U.S. 56 (1980).

${ }^{25}$ United States v. Inadi, 475 U.S. 387 (1986); Bourjaily v. United States, 483 U.S. 171 (1987).

${ }^{26}$ White v. Illinois, 502 U.S. 346 (1992).

${ }^{27}$ Ohio v. Roberts, 448 U.S. 56, 64 (1980).

${ }^{28} \mathrm{Id}$. at $70-73$.

${ }^{29} I d$. at 73 .

${ }^{30} \mathrm{Id}$. at 66. 
Roberts. Therefore Justice Blackmun's Roberts opinion did not explain which hearsay exceptions were firmly rooted and did not describe how to identify a particularized guarantee of trustworthiness.

No Supreme Court decision fully adopted the general theory described in Roberts. Both Justice Powell in Inadi $i^{31}$ and Chief Justice Rehnquist in White $e^{32}$ narrowed the application of Roberts by limiting its language about unavailability to a case involving prior testimony. Chief Justice Rehnquist invoked the Roberts language about firmly rooted exceptions in discussing co-conspirator statements in Bourjaily $^{33}$ and excited utterances in White, ${ }^{34}$ but neither opinion provided a test for determining which exceptions might be firmly rooted. Justice Brennan in Lee $e^{35}$ and Justice O'Connor in $\mathrm{Wright}^{36}$ discussed particularized guarantees of trustworthiness, but each case concluded that the evidence was not admissible so neither opinion had to define adequate guarantees of trustworthiness.

The strongest effort to build confrontation doctrine on Roberts was made by Justice Stevens in Lilly. ${ }^{37}$ The vote to reverse Lilly's conviction was unanimous, but only three other Justices joined the explanation Justice Stevens based on Roberts. ${ }^{38}$ Four other opinions provided different explanations. ${ }^{39}$ As a result, the Supreme Court ended the twentieth century with a body of confrontation opinions that addressed particular facts. The opinions had variously used, narrowed, or ignored the language about reliability from Roberts, but the Justices had not found a consensus on an overall theory of confrontation. That meant that trial and appellate courts had to rule on situations the Supreme Court had not yet addressed and had to apply the language of the Court's opinions to facts the Justices may not have had in mind.

\section{Crawford and The Evolution of the Testimonial Interpretation}

Crawford v. Washington ${ }^{40}$ announced a new interpretation of the Confrontation Clause to organize confrontation doctrine. In his opinion for the Court, Justice Scalia discussed English legal history from the Sixteenth to the Eighteenth Century, colonial

${ }^{31}$ United States v. Inadi, 475 U.S. 387, $392-94$ (1986).

${ }^{32}$ White v. Illinois, 502 U.S. 346, 353-54 (1992).

${ }^{33}$ Bourjaily v. United States, 483 U.S. 171, 182-83 (1987).

${ }^{34}$ White v. Illinois, 502 U.S. 346, 355-36 note 8 (1992).

${ }^{35}$ Lee v. Illinois, 476 U.S. 530, 543-46 (1986).

${ }^{36}$ Idaho v. Wright, 497 U.S. 805, 816-23 (1990).

${ }^{37}$ Lilly v. Virginia, 527 U.S. 116 (1999).

${ }^{38}$ Id. at 120 (Stevens, J., joined by Souter, Ginsburg \& Breyer, JJ.).

${ }^{39}$ Id. at 140 (Breyer, J., concurring); id. at 143 (Scalia, J., concurring); id. (Thomas, J., concurring); $i d$. at 144 (Rehnquist, C.J. \& O'Connor \& Kennedy, JJ., concurring in the judgment). See generally Roger W. Kirst, Appellate Court Answers to the Confrontation Questions in Lilly v. Virginia, 53 Syr.

L. Rev. 87, 93-103 (2003).

40541 U.S. 36 (2004). 
history, the debates over ratification of the United States Constitution, and early state court experience. ${ }^{41}$ From these sources he concluded that the Clause was directed at the use of ex parte out-of-court examinations as evidence against the defendant. ${ }^{42}$ Justice Scalia described such statements as "testimonial;" he offered three slightly different definitions of a "testimonial" statement but did not state which was most accurate. $^{43}$ He identified a statement to a police officer during interrogation as testimonial under any definition, without providing a definition of "interrogation" because the facts of Crawford involved structured police questioning that was an interrogation under any conceivable definition. ${ }^{44}$ Justice Scalia also concluded that the original meaning of the Clause required excluding any testimonial statement if the declarant did not appear as a witness at trial, unless the declarant was unavailable and the defendant had a prior opportunity to cross-examine the declarant. ${ }^{45}$

Justice Scalia described the testimonial interpretation as necessary to correct two problems with the Court's prior confrontation doctrine based on Roberts: the test under Roberts was too broad because it applied to all out-of-court statements, and its effect was too narrow because it allowed the prosecution to use a testimonial statement as long as the trial court found it was reliable. ${ }^{46}$ Justice Scalia did note that the Court itself had not been led very far astray by Roberts. ${ }^{47}$ However, some appellate courts were routinely allowing prosecutors to use accomplice confessions, grand jury testimony, and accomplice plea allocutions upon a finding that the hearsay was reliable. Justice Scalia concluded that the reliability standard had not provided meaningful protection because the tests for reliability that had been developed by the appellate courts were amorphous, subjective, and unpredictable. ${ }^{48}$

Crawford made clear that a critical issue would be the scope of the definition of a testimonial statement. At the core of the various definitions quoted by Justice Scalia were prior testimony, affidavits, and depositions; each was a situation in which the declarant was providing evidence under oath. ${ }^{49}$ The facts of Crawford itself established that custodial interrogation by the police would produce a testimonial statement. For some other statements the exact scope of the testimonial category was left unclear. For example, Crawford quoted both a definition that depended on the expectation of the declarant that a statement would be used prosecutorially and a definition that depended on the reasonable belief of an objective observer that the

41 Id. at $43-50$.

42 Id. at 50-51.

43 Id. at 51-52.

44 Id. at 53 n. 4.

45 Id. at 53-54.

46 Id. at 60.

47 Id.

48 Id. at 63.

49 Id. at 51-52. 
statement would be available for trial. ${ }^{50}$

Crawford had an immediate impact, particularly in the cases in which the prosecution had used a statement of an accomplice who did not appear at trial. Appellate courts that had been relying on Roberts to allow the prosecution to use grand jury testimony and plea allocutions without cross-examination changed course after Crawford and found admission of that kind of evidence to be a confrontation violation. $^{51}$ Four years after Crawford this appears to have become a permanent change.

The Supreme Court gave its first guidance on the scope of Crawford in Washington v. Davis, when it addressed confrontation rules for a victim's statement to law enforcement. ${ }^{52}$ In his Davis opinion for the Court, Justice Scalia put less emphasis on the belief or expectation of either the declarant or the police officer about any use of the statement; he put more emphasis on the purpose of the particular interrogation. He described a statement as nontestimonial if "the primary purpose of the interrogation is to enable police assistance to meet an ongoing emergency." ${ }^{53} \mathrm{He}$ described a statement as testimonial when there is no ongoing emergency and "the primary purpose of the interrogation is to establish or prove past events potentially relevant to later criminal prosecution." ${ }^{54}$ Justice Scalia avoided the issue of whose perspective mattered by describing the test as based on objective circumstances.

The result in Davis provided some illustrations of what the Court meant by an ongoing emergency. In Davis the declarant made the challenged statements to a 911 operator just after her assailant hit her and ran out the door. Justice Scalia described the statement in Davis as not testimonial because the declarant was seeking police assistance for an ongoing emergency, when the declarant still faced a "bona fide physical threat" because the assailant could return. ${ }^{55}$ In the companion case of Hammon $v$. Indiana, the complainant made the statements to responding police officers after the officers had separated the suspect from the complainant. Justice Scalia described the statement in Hammon as testimonial because the emergency had ended when the police officers secured the scene of the assault and took control of the suspect. ${ }^{56}$ Justice Scalia rejected the state court's position that "virtually any 'initial inquiries' at the crime scene" would produce nontestimonial statements. ${ }^{57} \mathrm{He}$ said that initial inquiries would often produce nontestimonial statements, but that the

$50 \mathrm{Id}$.

51 See, e.g., United States v. Hardwick, 523 F.3d 94, 98 (2 ${ }^{\text {nd }}$ Cir. 2008); United States v. Bruno, 383

F.3d 65, $78\left(2^{\text {nd }}\right.$ Cir. 2004).

52547 U.S. 813 (2006).

53 Id. at 822 .

${ }^{54}$ Id.

55 Id. at 826-27.

56 Id. at 829-30.

57 Id. at 832. 
response to an initial inquiry would be testimonial if the statements of a victim were "neither a cry for help nor the provision of information enabling officers immediately to end a threatening situation." ${ }^{58}$ In addition, Justice Scalia rejected the argument by Justice Thomas that the right of confrontation was limited to formal police interrogation. ${ }^{59}$

The emphasis on the immediate threat to the declarant also meant that the Davis definition of an emergency did not include the risk the suspect would commit the same harm in the future. Justice Scalia and the other seven Justices in the majority clearly did not accept the argument by Justice Thomas in his separate opinion that the police response to the emergency could include determining whether the suspect posed a continuing danger who might continue the assault after the police left. ${ }^{60}$ A similar argument for a broader definition of an "emergency" had been made by the State in its brief in Hammon $^{61}$ and by the Solicitor General in an amicus brief. $^{62}$

Davis had an immediate impact on the decisions of other appellate courts. Appellate courts have found that a statement is not testimonial if the victim was reporting an ongoing crime. ${ }^{63}$ They have found that a statement is not testimonial if it was made to the police before the officers were able to secure the scene. ${ }^{64}$ Other appellate courts have found that a statement is testimonial because it reported a past crime and there was no emergency still in progress. ${ }^{65}$

Even clear doctrinal statements in a Supreme Court opinion must still be interpreted by other courts. Many appellate opinions compare the facts of a case with the facts of Davis to determine if the statement was made while the declarant was facing an immediate emergency, ${ }^{66}$ but some opinions rephrase the language of Davis. For example, one court concluded that statements were nontestimonial because they

\footnotetext{
$58 I d$.

59 Id. at 830; see id. at 834, 840 (Thomas, J., concurring in the judgment in part and dissenting in part).

${ }^{60}$ Id. at 834, 840-41 (Thomas, J., concurring in the judgment in part and dissenting in part).

61 Brief of Respondent State of Indiana at 10-11, Davis v. Washington, 547 U.S. 813 (2006).

62 Brief of the United States as Amicus Curiae Supporting Respondent State of Indiana at 10-11, Davis v. Washington, 547 U.S. 813 (2006).

${ }^{63}$ E.g., Key v. State, 657 S.E.2d 273 (Ga. Ct. App. 2008); Commonwealth v. Nesbitt, 892 N.E.2d 299 (Mass. 2008).

64 E.g., People v. McKinney, 2008 WL 2031350 (Cal. Ct. App. 2008); Long v. United States, 940 A.2d 87 (D.C. 2007); State v. Shea, 2008 WL 3491404 (Vt. 2008).

${ }^{65}$ E.g., Cuyuch v. State, 2008 WL 4286646 (Ga. 2008); Allen v. Commonwealth, 2008 WL 2484952 (Ky. 2008); State v. J.A., 949 A.2d 790 (N.J. 2008); Zapata v. State, 232 S.W.3d 254 (Tex. Ct. App. 2007).

66 E.g., Lewis v. United States, 938 A.2d 771 (D.C. 2007); State v. Martin, 885 N.E.2d 18 (Ind. Ct. App. 2008); People v. Nieves-Andino, 872 N.E.2d 1188 (N.Y. 2007); State v. Graves, 157 P.3d 295 (Ore. 2007).
} 
were made during a "continuing emergency situation," a phrase the court used to allow the prosecution to use a statement that was made after the suspect was under control in handcuffs. ${ }^{67}$ In other cases courts use the description of an "ongoing" domestic or emergency situation as a sufficient label even though the facts in the opinion suggest that the declarant was not facing a threat at the time. ${ }^{68}$ For example, one court said there was an emergency when an officer asked a bystander for help while seeking a car that had turned into a residential subdivision shortly after the officer's radar indicated the car was speeding. ${ }^{69}$ Other courts may discuss whether there was an emergency when the statement was made, but suggest as well that a statement is nontestimonial as long as it is a response to "unstructured interrogation." 70

Some appellate courts also have used a broad interpretation of what it means to resolve an emergency. For example, one court described assessing the scene and resolving the emergency as including police efforts "to get information from the crime victim, calm her down, and relay information to other officers to apprehend a potentially dangerous suspect ... to protect the public." ${ }^{171}$ Another court described a statement as nontestimonial because the primary purpose of the police was determining whether the perpetrator had been apprehended and the emergency situation ended. ${ }^{72}$ These standards could extend the scope of an emergency well beyond any resemblance to the facts of Davis, but so far the Court has not reviewed whether these courts are properly extrapolating from Davis to new facts not considered in Davis.

Crawford left another issue undecided: whether the Confrontation Clause imposes any limits on the prosecution use of a nontestimonial statement. Justice Scalia said in Crawford that testimonial hearsay was at least the primary object of the Clause. ${ }^{73}$ He left open two possible rules for nontestimonial hearsay by suggesting that such hearsay might still be governed by Roberts or that it might not be subject to

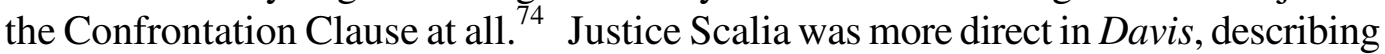
testimonial hearsay as both the core and the perimeter of the coverage of the Confrontation Clause. ${ }^{75}$ The Court finally made a definite statement about

${ }^{67}$ State v. Buckenberger, 984 So. 2d 751 (La. Ct. App. 2008).

${ }^{68}$ E.g., State v. Bonvillain, 2008 WL 2064978 (La. Ct. App. 2008); People v. Thompson, 2007 WL 2141416 (Mich. Ct. App. 2007).

${ }^{69}$ Segel v. State, 2008 WL 4140268 (Ga. Ct. App. 2008).

${ }^{70}$ E.g., People v. Osorio, 81 Cal. Rptr. 167 (Cal. Ct. App. 2008).

${ }^{71}$ State v. Koslowski, 2007 WL 1719930 (Wash. Ct. App. 2007). See also State v. Riley, 2007 WL 625898 (Ohio Ct. App. 2007).

${ }^{72}$ People v. Romero, 187 P.3d 56, 81 (Cal. 2008).

${ }^{73}$ Crawford v. Washington, 541 U.S. 36, 53 (2004).

${ }^{74} \mathrm{Id}$. at 68.

${ }^{75}$ Davis v. Washington, 547 U.S. 813, 824 (2006). 
confrontation limits on a nontestimonial statement in 2007 in Whorton v. Bockting, a case in which there was no nontestimonial statement. ${ }^{76}$ Nevertheless, in order to address whether Crawford was retroactive, Justice Alito had to examine how Crawford differed from Roberts. In that discussion he stated that under Crawford "the Confrontation Clause has no application to [nontestimonial] statements ..."77 That statement appears to explicitly confirm the suggestions in Crawford and Davis that there might be no confrontation limits on a nontestimonial statement.

The confirmation in Bockting that there is no confrontation limit on prosecution use of a nontestimonial statement appears to make the definition of a testimonial statement an all-or-nothing issue. Rejecting any room for flexibility in confrontation doctrine means that every new issue will test the Court's commitment to the testimonial interpretation.

\section{Forfeiture of the Right of Confrontation}

The Supreme Court addressed forfeiture of the right of confrontation in 2008 in Giles v. California. ${ }^{78}$ By that time the Court had signaled twice that a forfeiture rule was part of confrontation doctrine. In Crawford, Justice Scalia had described "the rule of forfeiture by wrongdoing (which we accept)" as part of confrontation doctrine. ${ }^{79}$ In Davis he provided a similar endorsement, but he did not try to define a standard for finding forfeiture. ${ }^{80}$

The primary issue that divided the Court in Giles was the standard for finding forfeiture. The defendant in Giles was charged with murdering his girlfriend; he testified the shooting was self-defense. At trial, the prosecution introduced statements the victim had made to a police officer who responded to an earlier domestic violence call. The State conceded the statements were testimonial, but the California courts held that the defendant had forfeited his confrontation objection by killing the declarant. Justice Scalia started his analysis from the proposition in Crawford that any confrontation exception had to be recognized at the time of the founding. ${ }^{81} \mathrm{He}$ surveyed the historical evidence and concluded that the forfeiture exception applied only when the defendant's conduct was designed to make the declarant unavailable. ${ }^{82} \mathrm{He}$ further described the standard as requiring purpose ${ }^{83}$ or

${ }^{76} 127$ S. Ct. 1173.

${ }^{77}$ Id. at 1183 .

78128 S. Ct. 2678 (2008).

${ }^{79}$ Crawford, 541 U.S. at 62.

${ }^{80}$ Davis, 547 U.S. at 833.

${ }^{81}$ Giles, 128 S.Ct. at 2682.

${ }^{82} I d$. at 2683.

${ }^{83} \mathrm{Id}$. 
intent $;{ }^{84}$ causing the declarant to be absent would not suffice if the defendant did not do so to keep the declarant from testifying at trial. ${ }^{85}$

Justice Scalia's opinion was supported in full by only Chief Justice Roberts. In his dissenting opinion, Justice Breyer argued that intentionally committing a wrongful act should suffice to forfeit confrontation rights if the likely consequence was that the declarant could not testify. ${ }^{86}$ Justice Breyer was supported by only Justice Stevens and Justice Kennedy. The reasoning of the other Justices complicates the task of interpreting Giles. Justice Scalia drew two more votes for vacating the California judgment from Justice Thomas and Justice Alito; both said they agreed with Justice Scalia's conclusions about forfeiture but would not have reached that issue if California had argued that the statement was not testimonial. ${ }^{87}$ Justice Scalia drew two additional votes to vacate the California judgment from Justice Souter and Justice Ginsburg. Justice Souter said in his concurring opinion that he was not persuaded by Justice Scalia's examination of the historical record but agreed with his conclusion on the grounds of logic and policy. ${ }^{8}$

The opinions in Giles also provided three views on how a prosecutor in a domestic violence case could prove that the defendant had the purpose to prevent the declarant from testifying. Justice Scalia stated that the evidence of the defendant's purpose could include the facts about the abusive relationship of the defendant and declarant; he did not state that those facts would be sufficient. ${ }^{89}$ Justice Souter suggested the requisite purpose or intent could be inferred in any classic abusive relationship. ${ }^{90}$ Justice Breyer argued that intentional misconduct should suffice for forfeiture if the defendant should have known that it would prevent the declarant from testifying. ${ }^{91}$ He also suggested that Justice Scalia's approval for using evidence from an abusive relationship would allow courts to find purpose from evidence of intent in a domestic violence case. ${ }^{2}$ The distinctions among the three positions may become blurred as appellate courts translate Giles into practical rules for trial courts. After Giles, some courts have rejected forfeiture arguments where the evidence did not show why the defendant acted, ${ }^{93}$ so Justice Scalia's insistence that there must be evidence of the defendant's purpose may prompt prosecutors to present some

84 Id. at 2684.

${ }^{85} \mathrm{Id}$.

86 Id. at 2695, 2705 (Breyer, Stevens \& Kennedy, JJ., dissenting).

87 Id. at 2693 (Thomas, J., concurring); id. at 2694 (Alito, J., concurring).

${ }^{88}$ Id. at 2694 (Souter \& Ginsburg, JJ., concurring).

89 Giles, 128 S. Ct. at 2693.

90 Id. at 2694, 2695 (Souter \& Ginsburg, JJ., concurring)

91 Id. at 2698.

92 Id. at 2708.

93 E.g., People v. Faz, 2008 WL 4294946 (Cal. Ct. App. 2008); United States v. Taylor, 2008 WL 4186934 (E.D. Tenn. 2008); Davis v. State, 2008 WL 3918050 (Tex. Ct. App. 2008). 
evidence about the specific relationship so that judges are not forced to rely exclusively on stereotypes.

The topic that is particularly of interest for the future development of confrontation doctrine is the way the Justices divided themselves into at least three groups with differing views on how strictly the Court should be bound by historical practice when it addresses a new confrontation issue. Justice Scalia continued to be the strongest advocate of closely following history; he repeated the statement from Crawford that the Sixth Amendment did not allow any "open-ended exceptions" to the right of confrontation. ${ }^{94}$ He rejected Justice Breyer's dissent as a "thinly veiled invitation to overrule Crawford and adopt an approach not much different from the regime of Ohio v. Roberts, ... under which the Court would create the exceptions that it thinks consistent with the policies underlying the confrontation guarantee, regardless of how that guarantee was historically understood." ${ }^{95}$

Justice Breyer's dissenting opinion presented the greatest contrast to Justice Scalia's reliance on history, even though Justice Breyer said it was "important to recognize the relevant history" and he agreed with Justice Scalia that an exception for forfeiture was established at the time of the founding. ${ }^{96}$ Justice Breyer's argument for a broader forfeiture rule went beyond the common law history by relying as well on basic purposes and objectives of the rule, similar equitable principles, an interest in avoiding evidence rules that are difficult to apply in practice, and an interest in avoiding incongruous or anomalous confrontation rules. He argued that lowering the confrontation barrier would allow the States to be more flexible in regulating the admission of hearsay "where the need is significant and where alternative safeguards of reliability exist." 97

Justice Souter created a middle position between Justice Scalia and Justice Breyer by joining all of Justice Scalia's opinion except for Part II-D-2, the section in which Justice Scalia suggested that Justice Breyer wanted to abandon Crawford and go back to Roberts. ${ }^{98}$ Justice Souter did not endorse Justice Scalia's reliance on the historical record alone because he found there were too few cases to answer the particular question in Giles. ${ }^{99}$ Justice Souter relied instead on his conclusion that Justice Breyer's version of forfeiture was based on near circularity in reasoning that would in practice lead back to the reliability interpretation of the Confrontation Clause that had been rejected in Crawford. ${ }^{100}$ Justice Souter's willingness to look

${ }_{95}$ Giles, 128 S. Ct. at 2692, quoting Crawford v. Washington, 541 U.S. at 54.

95 Id. at 2691.

96 Id. at 2695-96 (Breyer, Stevens \& Kennedy, JJ., dissenting).

97 Id. at 2700.

98 Id. at 2694 (Souter \& Ginsburg, JJ., concurring in part).

99 Id. at 2694-95.

${ }^{100}$ Id. at 2695. 
beyond the historical record might resemble Justice Breyer's argument for adding policy to history, but Justice Souter supported Justice Scalia's result in Giles; Justice Scalia did not comment on Justice Souter's explanation.

Justice Thomas presented a fourth position that cuts across the other three rather than being located along the same axis. ${ }^{101}$ Although he concurred with Justice Scalia's opinion and did not question the importance of allowing only historically recognized exceptions, the approach of Justice Thomas could align him with Justice Breyer in a case with different facts. The argument of Justice Thomas that informal police questioning does not produce a testimonial statement is based on an interpretation of the historical evidence that would leave informal statements to be regulated by state evidence rules. For informal statements, that would sometimes produce the same result as Justice Breyer's argument for adopting an easier standard for forfeiture that would leave more statements subject only to state evidence rules. Justice Alito's brief concurrence raising a similar question about the scope of the testimonial category suggests that Justice Thomas may have gained a new ally for his position. ${ }^{102}$

The publication of these different views suggests that the Justices were looking ahead in Giles. They may have been looking ahead already when it was argued. At oral argument, Justice Breyer was asking whether the Court had to incorporate every detail of the common law into confrontation doctrine when Justice Scalia interjected that the question had been answered in Crawford, and that Crawford was "[a] case from which [Justice Breyer] dissented."103 It took a few more exchanges before Justice Breyer could correct that misstatement by declaring: "I joined Crawford, and Justice Scalia would like to kick me off the boat, which I'm rapidly leaving in any event, but the -- (Laughter.)"104 The Giles opinions do not identify any specific cases the Justices might have been anticipating, but there are at least two candidates.

One confrontation issue the Justices may have had in mind in deciding Giles is whether there are any limits on the prosecution use of forensic test results without a witness. The Supreme Court had already granted the petition for certiorari in Melendez-Diaz on March 17, 2008, a month before Giles was argued on April 22. ${ }^{105}$ A second confrontation issue the Justices may have had in mind is prosecution use of hearsay statements of children in child abuse cases and sexual abuse cases. Two amicus briefs in Giles specifically presented arguments for admitting such statements

\footnotetext{
101 Id. at 2693 (Thomas, J., concurring).

102 Id. at 2694 (Alito, J., concurring).

103 Transcript of Oral Argument 11, Giles v. California, 128 S. Ct. 2678 (2008).

104 Id. at 13.

105 Melendez-Diaz v. Massachusetts, 128 S. Ct. 1647 (Mar 17, 2008) (No. 07-591).
} 
that ranged far beyond the issue of forfeiture. ${ }^{106}$ Prior to announcing Giles the Supreme Court had recently denied petitions for certiorari in at least three child sex abuse cases. ${ }^{107}$ The Court had also recently denied another petition for certiorari in a murder case involving a hearsay statement of a three-year old child in which the state court had concluded that the child's statement was testimonial. ${ }^{108}$

\section{The Next Issue: Experts and Certificates}

The Supreme Court will address a new confrontation issue in November when it hears Melendez-Diazv. Massachusetts. ${ }^{109}$ In this case, the defendant was arrested for selling cocaine by detectives acting on a tip. At his trial, the prosecution evidence included nineteen baggies containing a white powder. Instead of having an analyst testify about the contents of the baggies, the prosecution presented a drug analysis certificate that stated the baggies contained cocaine. The trial court overruled defendant's confrontation objection and admitted the certificate. In defendant's appeal from his conviction, the Massachusetts Appeals Court rejected defendant's confrontation objection in an unpublished memorandum:

In Commonwealth v. Verde, [444 Mass. 279 (2005)], the court held that certificates of drug analysis did not deny a defendant the right of confrontation and were, therefore, not subject to the holding in Crawford v. Washington, .... . We see no merit to the defendant's simple assertions that Verde is contrary to Crawford . . . 110

The Massachusetts Supreme Judicial Court denied review of Melendez-Diaz without an opinion, ${ }^{111}$ so the authoritative statement of Massachusetts law on a drug test certificate is still the opinion in Verde. In Verde, the Massachusetts Supreme Judicial Court concluded that state decisions from 1923 and 1969 that had rejected a

\footnotetext{
${ }^{106}$ Brief of the National Association to Prevent Sexual Abuse of Children's National Child Protection Training Center as Amicus Curiae in Support of Respondent, Giles v. California, 128 S. Ct. 2678 (2008); Brief of the National Association of Counsel for Children and the American Professional Society on the Abuse of Children in Support of Respondent, Giles v. California, 128 S. Ct. 2678 (2008).

107 Krasky v. Minnesota, 128 S. Ct. 1223 (Feb. 19, 2008); Bentley v. Ohio, 128 S. Ct. 1655 (Mar. 17, 2008); Muttart v. Ohio, 128 S. Ct. 2473 (May 19, 2008).

108 Ohio v. Siler, 128 S. Ct. 1709 (Mar. 24, 2008).

109 Commonwealth v. Melendez-Diaz, 870 N.E.2d 676 (Mass. App. Ct.) (unpublished opinion available at 2007 WL 2189152); rev. denied, 874 N.E.2d 407 (Mass. 2007); cert. granted, 128 S.Ct. 1647 (Mar 17, 2008) (No. 07-591).

1102007 WL 2189152 at $* 4$ note 3 .

111874 N.E.2d 407 (Mass. 2007).
} 
confrontation objection to certificates of analysis were still valid after Crawford. ${ }^{112}$ The Massachusetts court relied on four main reasons. First, the court explained that Crawford had recognized the continued validity of hearsay exceptions that were well-established at the framing, and asserted that in Crawford "the Court suggested in dictum that a business or official record would not be subject to its holding as this exception was well established in 1791."113 Second, the Massachusetts court concluded that a certificate should be considered a public record because it was neither discretionary nor based on opinion and stated the results of a scientific test. ${ }^{114}$ Third, the court described the certificate as only prima facie evidence that a defendant may rebut. ${ }^{115}$ Fourth, the Massachusetts court stated that a certificate was not like an ex parte examination that Crawford had said was the primary reason for the Confrontation Clause. ${ }^{116}$

The divisions among the Justices that were apparent in Giles may appear again when the Supreme Court decides Melendez-Diaz. There is even less chance in that case than in Giles that the Court will find clear guidance from history. The state of chemistry as a science in 1791 means there will be no precedent from the time of the framing specifically addressing the admissibility of an analyst's certificate of the chemical composition of a substance. Hearsay exceptions for business records and public records were still in an early stage of evolution; the records that were admitted under the hearsay exceptions were not like a certificate from an analyst who has tested contraband. The sparse historical record means that neither side can show that similar certificates were excluded or admitted, but that kind of reliance on history does not explain how the Court should decide the case.

Other state supreme courts and federal appellate courts have added arguments to the debate since the Massachusetts court concluded in Verde that a drug analysis certificate is not testimonial. The scope of the debate now extends beyond drug test certificates to include similar certificates reporting blood tests in drunken driving cases and certificates reporting DNA testing of an item related to a criminal prosecution. The courts that concluded that the prosecution cannot use a certificate by itself as proof of the test results have relied on the language and policy of Crawford. ${ }^{117}$ Crawford provided three different definitions of a testimonial statement. ${ }^{118}$ In two of the definitions an affidavit was listed as an example. In the

112 Commonwealth v. Verde, 827 N.E.2d 701, 704-05 (Mass. 2005).

113 Id. at 705.

114 Id.

115 Id.

116 Id. at 706.

117 State v. March, 216 S.W.3d 663, 666 (Mo. 2007), pet. for cert. dismissed, 128 S. Ct. 1441 (2007); State v. Caulfield, 722 N.W.2d 304, 308-10 (Minn. 2006); State v. Johnson, 982 So. 2d 672, 677-81 (Fla. 2008), cert. denied, Florida v. Johnson, 2008 WL 2950826 (U.S. 2008).

118 Crawford v. Washington, 36, 51-52 (2004). 
third definition a testimonial statement was one that objectively was made for use at a later trial. Under all three definitions the certificate in Melendez-Diaz would be a testimonial statement..

Recent appellate opinions have provided four additional arguments why Crawford does not bar the prosecution from using a test certificate without testimony from the analyst. Some courts distinguish Crawford with the argument that a lab test is neutral and not intended to incriminate or accuse. ${ }^{119}$ These courts stress that the analyst tests an object without knowing anything about the suspect or the rest of the case, and that the analysis may also exonerate a suspect. However, this argument often appears to equate the purpose of the test with the purpose of the certificate; it appears to lose its force if they are viewed separately. Even if the testing is objective and neutral, the purpose of the certificate is to provide an affidavit the prosecution can use to prove its case as a substitute for live testimony.

A second argument for distinguishing Crawford is that an analyst's certificate does not resemble an ex parte examination. ${ }^{120}$ Of course, it does not resemble the custodial interrogation in Crawford or even the noncustodial interrogation in Davis or Hammon, but this argument appears to depend on a very cursory comparison. A police officer may not question the analyst in the same way as the officer would question a complainant or a witness to a crime, but there is still a question from the police to the analyst about the amount and composition of suspected contraband. The analyst knows from experience what information to include in the certificate. Crawford did not define interrogation because a recorded statement in response to structured police questioning was clearly within any conceivable definition. ${ }^{121}$ Justice Scalia said nothing in Crawford about the length of the interrogation, especially where the declarant knows only one fact. However, there may be other views on the Court. The suggestion of Justice Thomas in Giles that only "'a formalized dialogue'" could produce a testimonial statement might lead him to conclude that the stylized questioning of a lab request means that the certificate is not a testimonial statement. ${ }^{122}$

A third argument for allowing the prosecution to use the certificate of an analyst who does not testify is that Davis excludes any contemporaneous statement from the testimonial category. ${ }^{123}$ This argument describes the certificate as a record

119 E.g., People v. Geier, 161 P.3d 104, 140 (Cal. 2007), pet. for cert. filed (U.S., No. 07-7770, Nov. 14, 2007); State v. O'Maley, 932 A.2d 1, 12-14 (N.H., 2007), pet. for cert. filed (U.S., No. 07-7577, Nov. 7, 2007); State v. Crager, 879 N.E.2d 745, 753-54 (Ohio., 2007), pet. for cert. filed (U.S., No. 07-10191, Mar. 26, 2008).

120 E.g., State v. O'Maley, 932 A.2d at 12-13.

121 Crawford v. Washington, 541 U.S. 36, 53 n. 4 (2008).

122 Giles v. California, 128 S.Ct. 2678, 2693 (2008) (Thomas, J. concurring).

123 E.g., United States v. Washington, 498 F.3d 225, 232 (4th Cir. 2007), pet. for cert. filed (U.S., No. 07-8291, Dec. 14, 2007); People v. Geier, 161 P.3d at 139-40; State v. O'Maley, 932 A.2d at 12; State 
of what the analyst is observing about the contraband at the time of the test. It depends on parsing the Davis test into its component parts and assuming that one part-the contemporaneous nature of the statement-is sufficient to make the certificate nontestimonial. This argument eliminates the other parts of the Davis test, such as the emergency and the declarant's fearful cry for help. In some opinions, this rationale includes an argument that the machine used to test a substance is essentially the source of the certificate and that there is no confrontation violation because a machine cannot be cross-examined. ${ }^{124}$

The final argument for allowing the prosecution to use an analyst's certificate is that requiring the analyst to testify in every drug trial would be too burdensome. The State's brief in Melendez-Diaz described the potential burden by citing statistics about millions of drug cases every year, tens of thousands of felony drug trials every year, and backlogs of testing requests in over one hundred thousand drug cases. ${ }^{125}$ In addition, the state contended that most defendants do not really intend to cross-examine the analyst, and that those who do cross-examine rarely accomplish anything. ${ }^{126}$ Amicus briefs supported that position at greater length. ${ }^{127}$ The State's brief in Melendez-Diaz suggested that the defendant's right to compel the analyst to attend should be an adequate alternative to confrontation. ${ }^{128}$ This final argument for avoiding the application of Crawford depends so much on an assumption that test certificates are reliable that it might succeed only if the Court overrules or retreats from Crawford's rejection of reliability. That seems unlikely; even in Crawford the Court maintained its record of never overruling any prior confrontation decision. At the same time, the potential burden of requiring analysts to appear at trial may lead some Justices to ask if there is a compromise position on test certificates that is still consistent with Crawford's interpretation of the historical evidence.

The effect of Melendez-Diaz on other confrontation questions will depend on the outcome, the reasoning in the opinion, how the opinion defines a testimonial statement, how strictly the opinion adheres to history, and the extent to which it explicitly considers the practical effect of any rule. Other cases the Court has recently declined to review or that are still pending on the Court's docket illustrate

\footnotetext{
v. Crager, 879 N.E.2d at 753-54.

124 E.g., Washington, 498 F.3d at 231.

125 Brief of Respondent Commonwealth of Massachusetts 59-62, Melendez-Diaz v. Massachusetts, cert. granted, 128 S. Ct. 1647 (No. 07-591, 2008).

126 Id. at 60-61.

127 Brief of the States of Alabama et al. as Amici Curiae in Support of Respondent 23-28, MelendezDiaz v. Massachusetts, cert. granted, 128 S.Ct. 1647 (No. 07-591, 2008); Brief of Amici Curiae The National District Attorneys Association et al. In Support of Respondent 10-27, Melendez-Diaz $v$. Massachusetts, id.

128 Brief of Respondent Commonwealth of Massachusetts 62-65, Melendez-Diaz v. Massachusetts, cert. granted, 128 S. Ct. 1647 (No. 07-591, 2008).
} 
some of the questions that are sure to arise after Melendez-Diaz. The list includes drug cases in which a witness did testify about the test results, but the witness was not the analyst who tested the drugs. ${ }^{129}$ It includes similar cases where the witness at trial was not the analyst who tested the blood sample in a prosecution for driving under the influence ${ }^{130}$ or the analyst who tested the DNA sample that identified the defendant. ${ }^{131}$ The Court's docket also includes a case in which the appellate court concluded that a test certificate was testimonial, but still allowed the prosecution to use a test certificate because the defendant had not complied with a state law that permitted the defendant to file a timely demand that the prosecution produce the analyst at trial. ${ }^{132}$ There is a pending case where the appellate court rejected a confrontation objection to the documents the prosecution used to prove that the equipment used by the analyst was properly calibrated. ${ }^{133}$ Other cases on the Court's docket that might be affected by Melendez-Diaz include a case in which the testimony of a coroner was based on the autopsy notes of an unavailable doctor. ${ }^{134}$

Justice Scalia provided relatively straightforward rules in both Davis and Giles, continuing the common-law approach to confrontation doctrine the Court has most often used. If that trend continues, the Court will seek an uncomplicated test to resolve Melendez-Diaz, even if the test may not resolve every question raised by other cases on the docket. The Justices may be able to decide Melendez-Diaz without the need to reconcile their differing positions on whether to consider policy as well as historical practice. If the Justices do revisit Crawford's reliance on history, they will find a rich store of academic commentary on the history of the Confrontation Clause from the last decade that refutes Justice Harlan's well-known lament that "the Confrontation Clause comes to us on faded parchment." 135

129 United States v. Moon, 512 F.3d 359 (7th Cir. 2008), cert. denied, Moon v. United States, 2008 WL 936911 (U.S. 2008) \& Alexander v. United States, 2008 WL 910056 (U.S. 2008).

130 United States v. Washington, 498 F.3d 225 (4th Cir. 2007), pet. for cert. filed, (U.S., No. 07-8291, Dec. 14, 2007); State v. O'Maley, 879 N.E.2d 1 (N.H. 2007), pet. for cert. filed, (U.S., No. 07-7577, Nov. 7, 2007).

131 People v. Geier, 161 P.3d 104 (Cal. 2007) pet. for cert. filed (U.S., No. 07-7770, Nov. 14, 2007); People v. Rawlins, 884 N.E.2d 1019 (N.Y. 2008), pet. for cert. filed sub nom. Meekins v. New York (U.S., No. 07-10845, May 9, 2008); State v. Crager, 879 N.E.2d 745 (Ohio 2007), pet. for cert. filed (U.S., No. 07-10191, Mar. 26, 2008).

132 Hinojos-Mendoza v. People, 169 P.3d 662 (Colo. 2007) pet. for cert. filed (U.S., No. 07-9369, Feb. 4, 2008); Magruder v. Commonwealth, 657 S.E.2d 113 (Va. 2008) pet. for cert. filed sub nom. Briscoe v. Virginia (U.S., No. 07-11191, June 6, 2008).

133 State v. Chun, 943 A.2d 114 (N.J. 2008), cert. denied, 2008 WL 2463761 (U.S. 2008).

134 United States v. De La Cruz, 514 F.3d 121 (1st Cir. 2008), pet. for cert. filed (U.S., No. 07-1602, June 23, 2008).

135 California v. Green, 399 U.S. 149, 172, 175-76 (1970) (Harlan, J., concurring). See generally Symposium: Crawford and Beyond: Exploring the Future of the Confrontation Clause in Light of its Past, 71 Brook. L. Rev. 1-427 (2005); Symposium: Crawford and Beyond: Revisited in Dialogue, 15 


\section{Looking Back and Ahead}

State and federal courts have adapted to Crawford without major problems on many confrontation topics, in large part because Crawford did not reverse any Supreme Court confrontation decision and left intact almost all of the specific answers the Court had previously provided. There were no pre-Crawford opinions on confrontation issues in domestic abuse cases, but the recent focus on domestic abuse prosecutions meant that the Court would have been asked eventually to address the issue. Crawford probably sped up the process by giving new prominence to confrontation doctrine that encouraged both prosecutors and defense counsel to try new methods and to advance new arguments. The same effect probably explains Melendez-Diaz and the large number of cases on the Court's docket that involve test results and expert testimony based on hearsay. Will the Court be able to take a break after Melendez-Diaz, or are there other major confrontation questions?

One topic that is appearing on the Supreme Court docket is confrontation limits on hearsay statements of children in child abuse and child sexual abuse cases. In 1989, in Idaho v. Wright, the Court reversed a conviction for lewd conduct with a minor that was based in part on statements a $21 / 2$ year old child made to a pediatrician. ${ }^{136}$ Idaho argued that the child's statements were admissible under the state residual hearsay exception; it argued that there was no confrontation violation because the content of the statement had particularized guarantees of trustworthiness. ${ }^{137}$ The majority opinion by Justice O'Connor described the pediatrician's examination without stating whether its purpose was treatment or prosecution or whether the child made her statements privately or to someone acting for the authorities. ${ }^{138}$ Wright concluded that the prosecution could not show guarantees of trustworthiness to satisfy the Roberts test by corroborating the content of the statement, and that the facts did not establish enough other guarantees. ${ }^{139}$

In 1992, in White v. Illinois, the Court affirmed a conviction for sexual assault that was based in part on statements the four-year old victim made to a nurse and doctor. The statements were admitted under the state's medical examination hearsay exception; the Supreme Court limited the grant of certiorari to the confrontation question and assumed that the challenged statements fit within the hearsay exceptions used by the state courts. The majority opinion by Chief Justice Rehnquist held that there was no confrontation violation because the medical examination exception was a firmly rooted hearsay exception.

J.L. \& Policy 333-904 (2007).

136497 U.S. 805 (1990).

${ }^{137}$ Id. at 819 .

${ }^{138} I d .$. at 809

${ }^{139} I d$. at $820-25$. 
In Crawford, Justice Scalia described the Court's prior confrontation cases as generally faithful to the testimonial interpretation; $;{ }^{140}$ he did not mention Wright when he summarized those prior cases even though he had joined Justice O'Connor's opinion. ${ }^{141}$ In Crawford, Justice Scalia suggested that White's holding that allowed the prosecution to use a statement to the police officer might not be consistent with the testimonial interpretation, but he said nothing about White's analysis of a statement during a medical examination. ${ }^{142}$ That silence left undecided the question of whether every statement to a medical professional would be nontestimonial under the new test adopted in Crawford. Justice Scalia stated in Giles that "statements to physicians in the course of receiving treatment" are nontestimonial, but that announcement also leaves some unanswered questions.

The split among appellate courts on whether statements by abused children to medical personnel are testimonial has not been addressed by the Supreme Court. The Court denied two recent petitions for certiorari from defendants. One case sought review of the holding of the Minnesota Supreme Court that statements for medical treatment were not testimonial; the interview of the child at a Children's Resource Center had been arranged by the police and a county family services worker. ${ }^{143} \mathrm{~A}$ similar case sought review of an Ohio Supreme Court case in which the police and the government were apparently not involved in arranging the original interview that was introduced at trial. ${ }^{144}$ The Court also denied a recent petition for certiorari in a case that reached the opposite result. In that case the Iowa Supreme Court held that statements were testimonial even though they were for medical treatment. The police and a state human services worker had arranged the proffered interview of a child at a Child Protection Center. ${ }^{145}$ The Court denied the petition in another case at the start of the term in October. ${ }^{146}$ There are also many other appellate opinions on each side of the dispute about the confrontation limits on prosecution use of a child's statements. Every judge and lawyer in such cases will undoubtedly read Melendez-Diaz closely for any restatement, revision, or extension of Crawford.

A second issue that might be affected by what Melendez-Diaz may say about confrontation doctrine is whether an indirect statement to the police can be testimonial. Some of the questions the courts will face are illustrated by a recent case in which a suicide note addressed to the author's parents accused the defendant of conspiracy to commit murder. The suicide note also said that the author was sending

140 Crawford v. Washington, 541 U.S. 36, 57-58 (2004).

141 Idaho v. Wright, 497 U.S. 805 (1990) (opinion of the Court by O'Connor, J, joined by Brennan, Marshall, Stevens \& Scalia, JJ.).

${ }^{142}$ Crawford v. Washington, 541 U.S. 36, 58 n. 8 (2004).

143 State v. Krasny, 736 N.W.2d 636 (Minn. 2007), cert. denied, 128 S. Ct. 1223 (2008).

144 State v. Muttart, 875 N.E.2d 5 (Ohio 2007), cert. denied, 128 S. Ct. 2473 (2008).

145 State v. Bentley, 739 N.W.2d 296 (Iowa 2007), cert. denied, 128 S. Ct. 1655 (2008).

146 Seely v. State, 373 Ark. 141 (2008), cert. denied, 2008 WL 2717763 (U.S. 2008). 
the proof to the police. The prosecution evidence included the suicide note and the contents of a briefcase the author of the suicide note had told his brother to look for under the author's bed if anything ever happened to the author. The Michigan courts held that the suicide note was admissible and rejected the defendant's confrontation objection. ${ }^{147}$ In a subsequent habeas action, the United States District Court had first to resolve some complex issues about retroactivity and the standard of review. The federal court then concluded that the suicide note was testimonial under Crawford and that the state court erred in admitting the note. ${ }^{148}$

The federal court evaluated the suicide note under the three definitions of a testimonial statement that were quoted in Crawford. ${ }^{149}$ The suicide note was not a formalized statement, but the content provides strong evidence that either the author or an objective witness would have expected that the prosecution would use the suicide note as evidence. The report of the United States Magistrate Judge had described the suicide note as "more consciously designed to provide incriminating evidence" than any hearsay, apart from a formalized testimonial statement such as an affidavit or deposition. ${ }^{150}$ However, the federal court did not mention the possibility that the suicide note might be nontestimonial because it was addressed to the author's parents and not directly to the police. Each of the statements in Crawford,Davis, and Giles, was made to law enforcement. Law enforcement would not typically be involved in the statements the Court has described as nontestimonial, such as "business records or statements in furtherance of a conspiracy" and "[s]tatements to friends and neighbors about abuse and intimidation, and statements to physicians in the course of receiving treatment."151 Perhaps the rationale or language the Court uses in deciding Melendez-Diaz will provide further guidance on whether a nominally private accusation can be a testimonial statement.

\section{Conclusion}

A decade ago, it might have seemed that confrontation doctrine was becoming so tied to the hearsay rule that it served no independent function. Crawford made the Confrontation Clause important again in its own right for prosecutors, defense counsel, and judges. One question rarely mentioned is whether the Confrontation Clause requires action from other branches of government as well. The adoption of the Confrontation Clause, as well as other parts of the Bill of Rights, was a commitment to a particular kind of federal criminal procedure. The incorporation

147 People v. Miller, 2003 WL 21465338 (Mich. Ct. App. 2003).

148 Miller v. Stovall, 2008 WL 3974313 (E.D. Mich. 2008).

149 Crawford v. Washington, 541 U.S. 36, $51-52$ (2004).

150 Miller v. Stovall, 2008 WL 3974313 at *22.

151 Giles v. California, 128 S. Ct. 2678, 2693 (2008). 
doctrine extended the obligation to state criminal procedure. The criminal procedure required by the Bill of Rights can appear expensive, particularly if the reasons it is required are discounted. In a case like Melendez-Diaz the additional cost of requiring the analyst to testify becomes more apparent. The briefs in Melendez-Diaz and the appellate opinions in similar cases that discuss costs and burdens assume that the current systems for testing and the presently available technology are all that is possible. Must the courts limit the cost of criminal procedure to the budget they can expect, or does the Confrontation Clause also impose an obligation on the legislature and executive to develop and fund a law enforcement system that allows the courts to follow constitutionally required procedure? 